\title{
Socio Environmental Attitudes amongst the Inhabitants of Border Mountain Regions Close to the Former Iron Curtain: The Situation in the Czech Republic
}

\author{
Lubomir Bartos, Martin Cihar
}

Faculty of Science, Institute for Environmental Studies, Charles University in Prague, Prague, Czech Republic. Email: lubomir.bartos@centrum.cz,mcihar@natur.cuni.cz

Received March 23 ${ }^{\text {rd }}, 2011$; revised April 28 ${ }^{\text {th }}, 2011$; accepted June $7^{\text {th }}, 2011$.

\begin{abstract}
A socio-environmental survey amongst the inhabitants of the Sumava National Park and of the Nove Hrady Mountains took place in the summers of 2003 (Sumava), 2006 and 2007 (the Nove Hrady Mts.). The main aim of the study was to record the opinions and attitudes of local inhabitants of the both regions towards environmental conditions, nature conservation, tourism, and to carry out their subsequent comparison. The objectives included that of ascertaining how and on which issues opinions and attitudes have the potential to be changed. The method of a structured interview and a random selection of interviewees provided us with 200 questionnaires in Sumava and 150 questionnaires in the Nove Hrady Mountains. The most noticeable differences between Sumava and Nove Hrady Mts. respondents were found with respect to the following topics: assessment of environmental conditions; the attitude to potential public access to the most endangered parts of the nature; perceptions about the influence of tourism on the cost of living. Similar reflections were found in the assessment of personal profit from the tourist industry in the region.
\end{abstract}

Keywords: Local Inhabitants, Social Climate, Perceptions

\section{Introduction}

For the management of biologically valuable or protected areas, there is a necessity for good quality relations and agreement among the three key players: the conservation management, the local inhabitants and the visitors/tourists. This article deals with the opinions of local inhabitants and with their reflections on selected aspects of nature and area conservation and tourism in the area in which they live.

Participatory management cannot work without efficient communication with the public, which means communication with: the professionals, laymen, entrepreneurs and stakeholders [1]. It is a generally accepted fact that the public needs to be informed, educated and encouraged to participate in the management and development of their area. Such an approach helps in winning larger public interest, support and responsibility for the area (conflicts and problems often rise from a lack of knowledge). Both residents and visitors should have easy access to information on area management $[1,2]$.
The basis of many studies dealing with the role of local communities in nature conservation is formed around the idea that the inhabitants who have been living in a certain area for many generations use the available natural resources with regard to their natural renewal [3-5]. The autochthonous communities usually have a close relationship with nature and a deep knowledge of ecological processes [6]. This relative harmony between humans and the landscape is generally accepted but its explanation is still a subject of discussion. Is the equilibrium caused by the deep knowledge of the environment shared by the indigenous people and by their considerate farming methods or is it based on the low effectiveness of the local technologies, the historically low density of population and by limited access to the economic market [7]? There is, however, a different point of view: one of the basic problems of the protected areas is the fact that during the process of their establishment, the needs and the opinions of the local communities are usually not taken into consideration. The residents then often feel it to be 
unjust that someone who does not live in their region has established a protected area and in this way can ban or limit the activities which have been normal amongst the local population for generations, without asking them. Consequently, the existence of many conservation areas is perceived by their inhabitants in a negative way [6]. Their reactions are often unhelpful, and even hostile.

Worldwide experience of the authorities from national parks shows that the principle of "fences and fines" which has been applied until recently, has failed to protect biodiversity and various territorial units [8]. The most frequently used method of nature and landscape conservation consisted of isolating and limiting use of a particular area. The settlements and the local inhabitants were the most affected when they were cut off from their traditional means of subsistence. This aspect is still very often sidelined or ignored when protected areas or national parks are established [6]. The traditional activities of the local inhabitants in the newly established protected areas then paradoxically become unwanted or even illegal [9]. For that reason, we should change the paradigm now, at least where it is possible. The modern concept of a reserve should function as a cooperating organism, not as an isolated segment [10].

The whole range of problems which we encounter in conservation management is simply caused by a lack of connection between the deciding authority and the needs of the local community [11]. We still see situations when, for example, regional planning corresponds neither with the actual resources of the area, nor with the ideas of the local inhabitants [12]. For those reasons, alternative approaches have been designed. These approaches accept the needs of the local inhabitants. They are, for example, Community-Based Wildlife Management (CWM) [13], Ecosystem Management (EM) [14], Community-Based Management (CBM) [15].

However, these newly introduced approaches can also cause problems or conflicts. Practical experience shows that the new approaches do not necessarily lead to shared power but, on the contrary, to the strengthening of state influence and control over regional and especially local politics and management. The main cause is the fact that in the process of asserting their interests, state institutions always will be more effective than ordinary people [16].

It is therefore very likely that the existing conflict of interest will persist - the effort of local inhabitants to introduce new and productive technologies will collide with the effort of biologically oriented conservationists to conserve endangered ecosystems [7]. The above mentioned approaches not usually completely eliminate this conflict. However they offer a more efficient and more democratic approach to the problem. In reality, nature conservation will probably always stand in the way of a devastating exploitation of natural ecosystems and therefore in the path of fast technological and economic development in some parts of the world [15], any development which is generated by the principles of democratization, commercialization, and the omnipresent globalization.

Sustainable development of the landscape does not require only its protection but, perhaps most of all, the participation of local inhabitants in the process of its formation and planning [17]. For this reason, social climate is the key factor in the successful management of protected areas, and that is why there are growing numbers of surveys dealing with the attitudes and opinions of the inhabitants of these areas. The first works on the subject started appearing in the late 1970s and early 1980s [18-21]. Further studies followed and for illustration purposes, there are some examples: [3-5,9,15,17,22-31].

So far there have been only a few cases where an individual survey has become part of a study of trends or even of systematic, long-term monitoring. For example in the Czech Republic there has been a scheme since the nineties which continuously monitors the social climate in protected areas, large and small $[32,33]$.

This article deals with the areas of the Sumava National Park (well-known and traditional tourist destination) and the Nove Hrady Mountains (new discovered tourist destination), where the establishment of Protected Landscape Area has been intended for twenty years-Have these differences influence on the mind, perceptions and characteristics of the local people?

The Sumava National Park and Biosphere Reserve is a bilateral national park (National Park Bayerischer Wald on the German side of the borders) situated by the southwest borders of the Czech Republic. It was estabilished in 1991. Sumava is the largest mountain Czech national park, its area is $690 \mathrm{~km}^{2}$. Objects of the protection are mountain forests, moorlands and meadows. The Nove Hrady Mts. are situated by the south borders of the Czech Republic. They form a natural border between the Czech Republic and Austria. Its area is $162 \mathrm{~km}^{2}$, and is continued in the south by a similar-sized Austrian region. The two oldest protected areas in Central Europe are located here: Zofin Primeval Forest and Hojna Voda Forest (1838). The current level of protection in the form of a natural park (the primary purpose of which is to protect landscape features) is from a long-term point of view of Ministry of the Environment insufficient. Even the listing of selected segments of local nature and landscape in the European conservation system NATURA 
2000 is not adequate for the complex and balanced protection management required in the Nove Hrady Mountains. For 20 years there has been an effort of conservationists on the Czech side to establish a protected landscape area here. The area would be in category IV according to IUCN-Habitat/Species Management Area. The effort constantly meets with resistance from local politicians and part of local people. Local people are afraid of bans and restrictions on development of area, restriction of entrance into the forest, drop in prices of land. They do not believe Ministry's promises of free entry into forests, investments and grants. They would like to have guarantees.

The number of registered commercial beds in Sumava (not only in national park but in wider region) is approximately 18801 . One bed falls on 8.8 inhabitants of region. The most frequent forms of accommodation are hotels and pensions. Visit rate of Sumava is approximately 600000 visitors a year [34]. Total number of registered commercial beds in Nove Hrady Mts. region is approximately 1731 , it is quite low number. One bed falls on 30 inhabitants of region. There is the most frequent forms of accommodation are objects for individual recreation-cottages. Most of their owners originate from Ceske Budejovice agglomeration [34]. There are large differences in tourist infrastructure between traditional tourist destination Sumava and new discovered tourist destination - the Nove Hrady Mts.

\section{Methodology}

The surveys were of a qualitative character, and the top- ics were focused on different aspects of protection management, tourism and as they were perceived by the inhabitants of selected villages in the Sumava NP and the Nove Hrady Mountains. A qualitative questionnaire survey method was selected for the purposes of the subsequent generalization of the results for the whole population of the area [35].

Qualitative research is a method of inquiry appropriated in many different academic disciplines, traditionally in the social sciences, but also in market research and further contexts [36,37]. Qualitative researchers aim to gather an in-depth understanding of human behavior and the reasons that govern such behavior [36,38]. The qualitative method investigates the why and how of decision making, not just what, where, when. Hence, smaller but focused samples are more often needed, rather than large samples [37].

In the summer of 2003, the survey took place in Sumava villages: Borova Lada, Horska Kvilda, Kvilda, Modrava, Srni and Prasily, 200 questionnaires were collected. In the summer of 2006 and 2007, the study continued in the Nove Hrady Mts.: Benesov nad Cernou, Nove Hrady, Pohorska Ves, and Horni Stropnice with the hamlets Hojna Voda and Dobra Voda. Altogether, 150 questionnaires were collected (see Figure 1). The relatively long time gap between the data collection and their publishing is due to the fact that the authors were intensely involved in surveying and publishing data obtained from visitors and tourists in the Czech Republic's protected areas. Thus, interesting data collected among the local population has been slightly overshadowed and processed later.

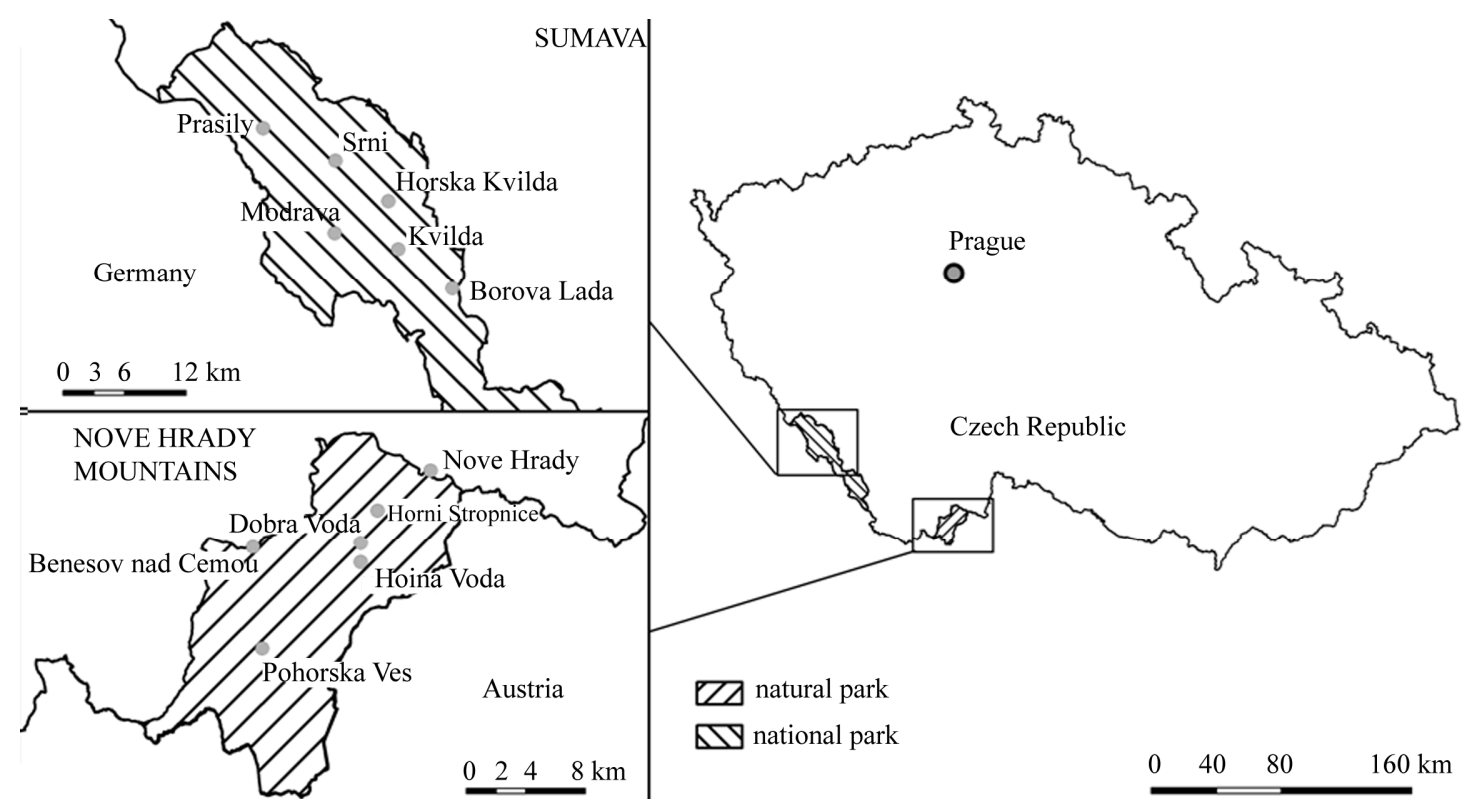

Figure 1. Map of the survey localization. 
They are only being published now.

The basic technique for data collection was the structured interview [39], allowing direct interaction with the respondent. The tool used for the interview was a standard questionnaire. During the individual interviews, the respondents could not influence each other. In this way high-quality and representative data were obtained [3]. The respondents were personally involved in the issue and their personal creativity could be used for gaining additional valuable information and authentic views.

\subsection{The Questionnaires and the Selection of Respondents}

Open, closed, semi-open, alternative, selective and scale questions were used [39]. Communication with the inhabitants and the sharing of information is another important role of the project $[32,40,41]$. The respondents were chosen by simple random sampling (probability sampling). It is presumed that every part of the population had an equal chance to be involved in the selection set $[3,42]$. Method of Random route sampling was used. This method is used in research surveys - mainly for sampling households, shops, garages and other premises in urban areas [3,26,29].

It was not possible to make selection from electoral or inhabitant's register and selection from phone book is not accurate. It was used different method of selection, after arrival to village it was selected left or right part along the main road by lot and consequently it was by lot selected number from one to the five and then it was visited every nth (first, second, third, fourth, fifth) address $[3,26]$.

The questionnaires were filled in individually and anonymously, the heading containing only the date and the place name. The introduction contained condensed information about the purpose of the survey.

The questionnaires were divided in the standard way into several thematic blocks. The first block dealt with the demographic characteristic of the respondent, next block Environment and nature in the area with reflections about environmental management, environmental conditions and their assessment. The third block was called Tourism. It was focused on the assessment of the economic effects of tourism and on the perception of the intensity of tourism by the local inhabitants. The respondents assessed the effect of tourism on the cost of living.

\subsection{Data Processing}

The results from the surveys, i.e. the individual answer sheets were converted into a table program MS Access, in which the primary data processing was carried out and the frequencies of the answers calculated. The frequencies and results of filtering were subsequently transfered into the program MS Excel, in order to compose the tables and charts.

Further processing was carried out in the program Statgraphics Plus, version 3.1. The statistically significant differences in the spectra of answers from respondents were tested using the chi square test $\chi^{2}$ at the significance level of $0.05(5 \%)$ [43].

\section{Results}

\subsection{Demographic Data}

Women predominated, both in Sumava group of respondents $(52.5 \%)$ and in the Nove Hrady Mountains group of respondents (analogically $60 \%$ ). There was no significant difference between the answers from the groups $\left(\chi^{2}\right.$ $=0.87 ; \mathrm{d} f 1 ; p=0.3508$ ).

Most of Sumava respondents came from the age group of 25 - 39 years (35\%), followed by the group of $40-59$ years $(33.5 \%)$. In the Nove Hrady Mountains group, the structure was similar, dominated by the age group $40-59$ (34\%) years, followed by the 25 - 39 age-group (30.7\%). In the parallel age-group structures, next came people aged 60 and over, then young people aged 18 - 24 years, and finally the $15-17$ age group. The statistical method did not find any significant difference between the groups $(p=0.8587)$.

The most frequent answer was secondary education, $37.5 \%$ in Sumava and $48 \%$ in the Nove Hrady Mts. The Sumava group of respondents has a higher representation of university graduates: $18.0 \%$, as opposed to $14.7 \%$ in the Nove Hrady Mts. There was no significant difference between the groups $(p=0.5306)$.

The following Tables (1 and 2) compare the resulting basic demographic characteristics of our respondents with the overall population of the Czech Republic. From the tables it is clear (at a probability level of 0.05 ) that the population characteristics of the both respondents group are in agreement with the characteristics of the overall Czech population as far as the age groups are concerned. On the other hand, large differences were found in the gender and education structures.

The following Tables (3 and 4) show development of number of population in surveyed villages in Sumava and Nove Hrady Mts. Population of selected villages in Sumava decreased between years 1991 (establishment of national park) and 2008, in Nove Hrady Mts. we can see increase. It could be caused by lack of job opportunity in the Sumava National Park, or by restrictions for living in national park. Increase in Nove Hrady Mts. could be caused by longing to live in clean environment.

Figure 2 shows assessment of environmental conditions in the areas in recent years (approximately from the 
Table 1. Comparison of the respondents' population from Sumava with the corresponding data for the Czech Republic. Source: CZSO (The Czech Statistical Office), 2008.

\begin{tabular}{|c|c|c|c|c|c|c|c|}
\hline $\begin{array}{c}\text { Sumava } \\
\text { Percentage }\end{array}$ & $\begin{array}{c}\text { Whole } \mathrm{CZ} \text { population } \\
\text { over } 15 \text { years }\end{array}$ & $\begin{array}{c}\text { Respondents } \\
\text { population Sumava }\end{array}$ & $\mathrm{s}$ & $\mathrm{T}$ & $\mathrm{T}^{\prime}$ & $\mathrm{z}_{0.05}$ & $\begin{array}{c}\text { Random difference ? } \\
\left(\mathrm{T}^{\prime}<\mathrm{z}_{0.05}\right)\end{array}$ \\
\hline \multicolumn{8}{|l|}{ Sex } \\
\hline Male & $48.4 \%$ & $47.5 \%$ & 0.035 & 2.07 & 2.00 & 1.96 & no \\
\hline Female & $51.6 \%$ & $52.5 \%$ & 0.035 & 2.07 & 2.00 & 1.96 & no \\
\hline \multicolumn{8}{|l|}{ Age group } \\
\hline $15-17$ & $4.4 \%$ & $2.5 \%$ & 0.015 & 0.96 & 0.78 & 1.96 & yes \\
\hline $18-24$ & $10.9 \%$ & $10.0 \%$ & 0.022 & 0.62 & 0.50 & 1.96 & yes \\
\hline $25-39$ & $27.7 \%$ & $35.0 \%$ & 0.032 & 0.81 & 0.73 & 1.96 & yes \\
\hline $40-59$ & $32.9 \%$ & $33.5 \%$ & 0.033 & 0.29 & 0.21 & 1.96 & yes \\
\hline Over 60 & $24.1 \%$ & $19.0 \%$ & 0.030 & 1.17 & 1.09 & 1.96 & yes \\
\hline \multicolumn{8}{|l|}{ Education } \\
\hline Elementary & $23.4 \%$ & $13.5 \%$ & 0.035 & 4.47 & 4.37 & 1.96 & no \\
\hline Trained & $38.6 \%$ & $24.0 \%$ & 0.040 & 3.85 & 3.77 & 1.96 & no \\
\hline Secondary & $25.3 \%$ & $37.5 \%$ & 0.036 & 6.38 & 6.29 & 1.96 & no \\
\hline Higher & $3.5 \%$ & $7.0 \%$ & 0.015 & 1.65 & 1.43 & 1.96 & yes \\
\hline Graduate & $9.1 \%$ & $18.0 \%$ & 0.023 & 2.40 & 2.25 & 1.96 & no \\
\hline
\end{tabular}

Note: s, T, T' are the testing statistic coefficients for the representativeness checkof $\alpha=0.05$.

Table 2. Comparison of the respondents' population from Nove Hrady Mts. with the corresponding data for the Czech Republic Source: CZSO (The Czech Statistical Office), 2008.

\begin{tabular}{|c|c|c|c|c|c|c|c|}
\hline $\begin{array}{c}\text { Nove Hrady Mts. } \\
\text { Percentage }\end{array}$ & $\begin{array}{c}\text { Whole } \mathrm{CZ} \text { population } \\
\text { over } 15 \text { years }\end{array}$ & $\begin{array}{l}\text { Respondents population } \\
\text { Nove Hrady Mts. }\end{array}$ & $\mathrm{s}$ & $\mathrm{T}$ & $\mathrm{T}^{\prime}$ & $\mathrm{z}_{0,05}$ & $\begin{array}{c}\text { Random difference? } \\
\left(\mathbf{T}^{\prime}<\mathrm{z}_{0.05}\right)\end{array}$ \\
\hline \multicolumn{8}{|l|}{ Sex } \\
\hline Male & $48.4 \%$ & $40.0 \%$ & 0.041 & 2.07 & 1.99 & 1.96 & no \\
\hline Female & $51.6 \%$ & $60.0 \%$ & 0.041 & 2.07 & 1.99 & 1.96 & no \\
\hline \multicolumn{8}{|l|}{ Age group } \\
\hline $15-17$ & $4.4 \%$ & $6.0 \%$ & 0.017 & 0.96 & 0.76 & 1.96 & yes \\
\hline $18-24$ & $10.9 \%$ & $9.3 \%$ & 0.025 & 0.62 & 0.48 & 1.96 & yes \\
\hline $25-39$ & $27.7 \%$ & $30.7 \%$ & 0.037 & 0.81 & 0.72 & 1.96 & yes \\
\hline $40-59$ & $32.9 \%$ & $34.0 \%$ & 0.038 & 0.29 & 0.20 & 1.96 & yes \\
\hline Over 60 & $24.1 \%$ & $20.0 \%$ & 0.035 & 1.17 & 1.08 & 1.96 & yes \\
\hline \multicolumn{8}{|l|}{ Education } \\
\hline Elementary & $23.4 \%$ & $8.0 \%$ & 0.035 & 4.47 & 4.37 & 1.96 & no \\
\hline Trained & $38.6 \%$ & $23.3 \%$ & 0.040 & 3.85 & 3.77 & 1.96 & no \\
\hline Secondary & $25.3 \%$ & $48.0 \%$ & 0.036 & 6.38 & 6.29 & 1.96 & no \\
\hline Higher & $3.5 \%$ & $6.0 \%$ & 0.015 & 1.65 & 1.43 & 1.96 & yes \\
\hline Graduate & $9.1 \%$ & $14.7 \%$ & 0.023 & 2.40 & 2.25 & 1.96 & no \\
\hline
\end{tabular}

Note: s, T, T' are the testing statistic coefficients for the representativeness check-testing statistic THD 5. The testing was carried out on the significance level of $\alpha=0.05$. 
Table 3. Population of surveyed villages in Sumava; Source: CZSO (The Czech Statistical Office), 2008.

\begin{tabular}{ccc}
\hline SUMAVA & $\mathbf{1 9 9 1}$ & $\mathbf{2 0 0 8}$ \\
\hline Borova Lada & 364 & 273 \\
Horska Kvilda & 27 & 78 \\
Kvilda & 169 & 183 \\
Modrava & 53 & 55 \\
Prasily & 144 & 155 \\
Srni & 368 & 275 \\
& 1125 & 1019 \\
\hline
\end{tabular}

Table 4. Population of surveyed villages in Nove Hrady Mountains; Source: CZSO (The Czech Statistical Office), 2008.

\begin{tabular}{ccc}
\hline NOVE HRADY MTS. & $\mathbf{1 9 9 1}$ & $\mathbf{2 0 0 8}$ \\
\hline Benesov nad Cernou & 1137 & 1379 \\
Horni Stropnice & 1523 & 1567 \\
Nove Hrady & 2673 & 2558 \\
Pohorska Ves & 309 & 315 \\
& 5642 & 5819 \\
\hline
\end{tabular}

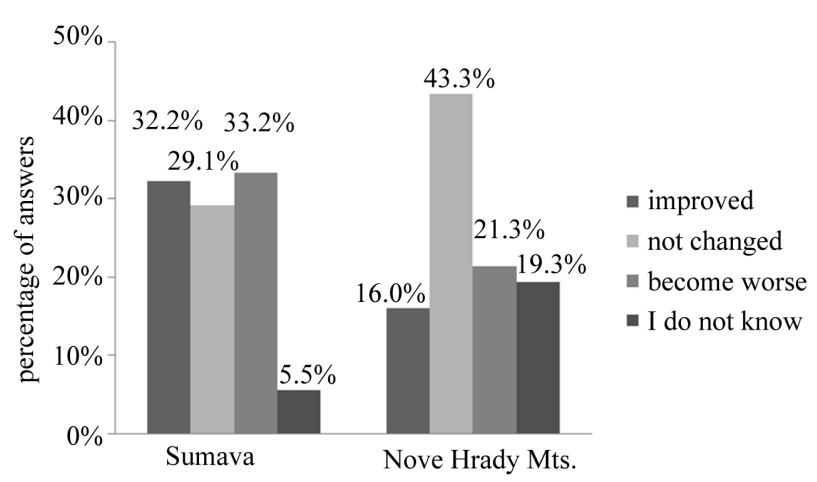

Figure 2. Assessment of the environmental conditions in region in recent years (approx. since 2000).

year 2000) by local people. Statistical evaluation of the answers showed a significant difference between the groups in their answers to this question $(p=0.0006)$.

\subsection{Environment and Nature in the Area}

Majority of respondents (62\%) in Sumava know about an environmental problem, compared to $24.7 \%$ in the Nove Hrady Mts. The most frequent answer in Sumava was bark beetle, in the Nove Hrady Mts. was excessive logging and absence of farming and forest management. The groups showed a significant difference in this aspect $(p=$ 0.0000 ). The predominant majority of Sumava respondents cumulatively stated that access to the disputed regions should not be made possible-72.3\% (Figure 3).

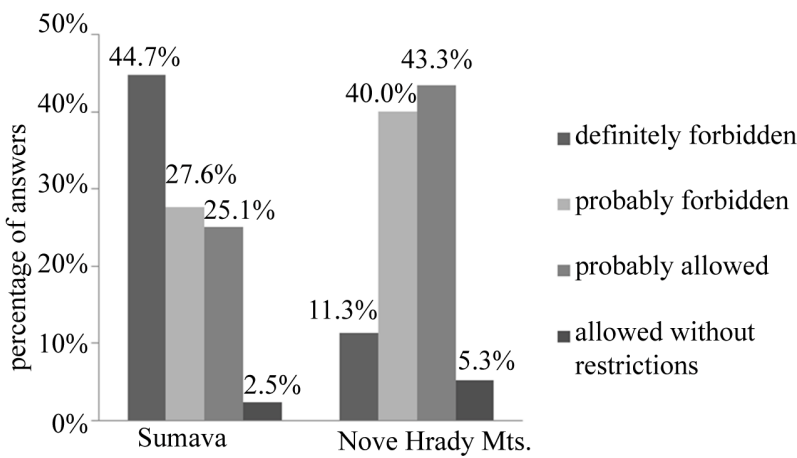

Figure 3 Attitudes of the respondents to the issue of tourist access to the most endangered parts of nature.

In the case of regulated access of tourists to such natural areas, they would give preference to "access with a guide" (55\%), followed by "other way of regulation" (24.1\%), "time-limited access" (16.2\%), and "introduction of a fee" (4.7\%). A smaller section (48.6\%) of the Nove Hrady Mts. respondents thought that access to the places with most endangered environment "should probably be allowed" or "should be allowed without restrictions". More than half $(51.4 \%)$ of the same resource of respondents had the opposite opinion. In the case of regulated access of tourists to such natural areas, they would give preference to "access with a guide" $(66 \%)$, followed by "timelimited access" (18\%), "introduction of a fee" $(9.3 \%)$ and "other way of regulation" (6.7\%).We can see a significant difference in the answers to both questions, concerning tourist access generally $(p=0.0000)$ and regulated access $(p=0.0090)$.

Respondents in Sumava thought that the current state of nature conservation in Sumava is satisfactory (35.7\%), $17.9 \%$ of the same group answered that it is "rather strict", $16.8 \%$ assessed it as "rather soft", $14.8 \%$ as "too soft" and $9.2 \%$ as "too strict". The remaining respondents either did not know or did not have an opinion. The majority of Nove Hrady Mts. respondents thought that the current state of nature conservation in the Nove Hrady Mountains is satisfactory ( $46 \%), 22 \%$ of the same group answered that it is "rather soft", $12 \%$ that it is "too soft", according to $8 \%$ it is "rather strict" and only $0.7 \%$ chose the answer "too strict". $11.3 \%$ of the same group either did not have an opinion or did not want to answer. With this question also, a significant difference in answers between the two groups can be observed ( $p=0.0162$ ).

\subsection{Tourism}

Figure 4 shows, economic benefit of local people from the tourist industry in the Sumava National Park and in the Nove Hrady Mts. There was no significant difference between the groups $(p=0.1075)$. 


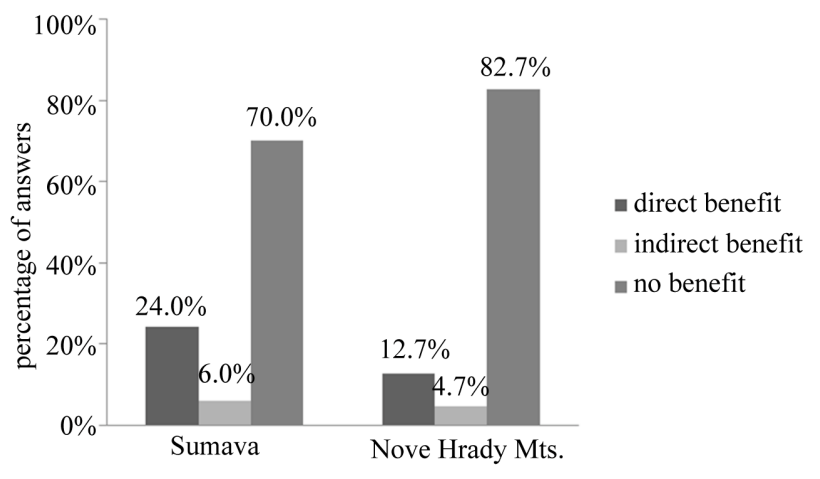

Figure 4. Economic benefit from the tourist industry.

According to the majority of Sumava respondents $(55.5 \%)$, the numbers of visitors in the region approximately around the time of the survey were increasing rapidly or moderately. Similar situation is in the Nove Hrady Mts. The majority of respondents (86\%) thought that, the numbers of visitors were increasing rapidly or moderately. Figure 5 shows detailed results. There was a significant difference in the answers to this question $(p=$ 0.0000).

The majority of Sumava (67.8\%) and Nove Hrady Mts. (78.7\%) respondents does not mind the intensity of tourism on the tourist routes. The intensity of tourism near the respondents' residence was perceived in a similar way: $68 \%$ of Sumava and $79.3 \%$ of the Nove Hrady Mts. respondents did not find it disturbing. The groups showed a significant difference in the intensity perception of tourism on the tourist routes $(p=0.0173)$ and also in perception of the intensity of tourism near the respondent's residence ( $p=0.0217$ ). According to Sumava respondents the presence of tourists more likely $(27.8 \%)$ or definitely $(46.5 \%)$ raises their cost of living in comparison to other regions. According to Nove Hrady Mts. respondents the presence of tourists more likely $(35.3 \%)$ or definitely $(23.3 \%)$ raises their cost of living in comparison to other regions. More in Figure 6. There is a significant difference in the answers to this question between the two groups $(p=0.0037)$.

\section{Discussion}

\subsection{Environment and Nature in the Area}

The majority of Sumava respondents chose the answer "the environmental conditions have become worse", followed by "the conditions have improved". The majority of residents in the Nove Hrady Mts. reported that the quality of the environment had not changed or had declined over the past 10 years. A survey in the smaller Podyji NP showed that the majority of local inhabitants thought that conditions had not changed [33]. The situa-

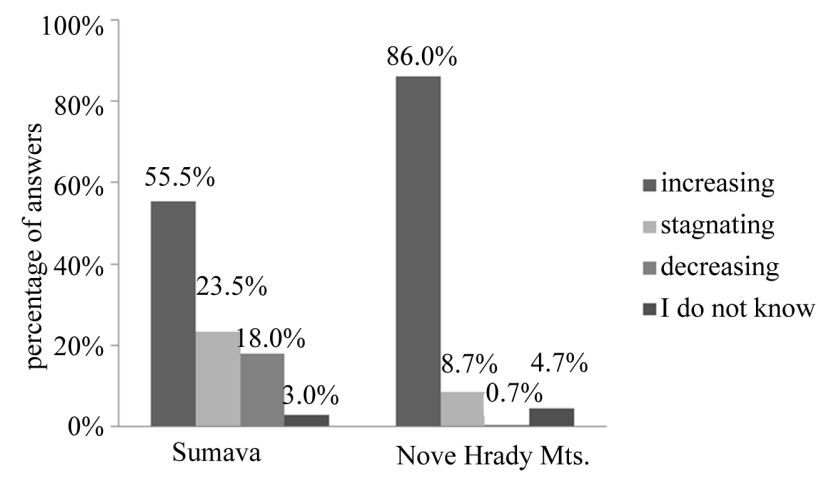

Figure 5. Number of visitors in both regions.

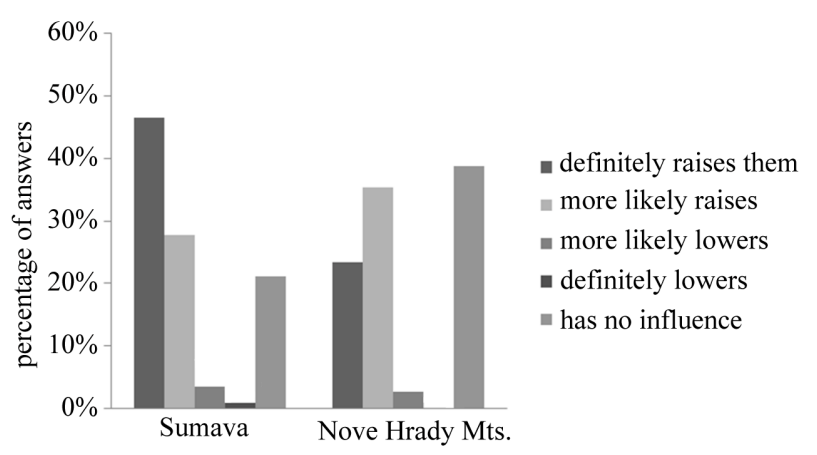

Figure 6. Assessment of the influence of the presence of tourists on the height of the cost of living.

tion in the oldest Czech national park (Krkonose) sounds much more optimistic [44]. A possible explanation could be based on the connection with both a subconscious and a rational perception of the national park as an institution primarily caring for the environment. This is too a large extent connected to the virtual image of the large national parks created by the media, while a certain part is also played by the respondents' need to believe and identify with the media image, which is not always completely realistic or accurate. Local people in Sumava perceive negatively long-term disputes about solution to bark beetle calamity. They do not agree with access of the national park management - holding of dead trees in forest. Locals think that dead trees should be chopped down and carried away.

They see dead standing trees that is why they think, that environmental conditions have become worse.

Majority of respondents in Sumava knows about an environmental problem, compared to the Nove Hrady Mts., where only minority of respondents knows about this problem. Locals in Nove Hrady Mts. reported the lowest knowledge of a specific ecological problem from the all monitored areas in the Czech Republic. For comparison: in the Podyji NP in 2000, 48.3\% of the locals new about a concrete environmental problem and in the 
Krkonose NP it was 57.1\% [44]. The most frequent answer in Sumava was problem with bark beetle, in the Nove Hrady Mts. it was excessive logging and absence of farming and forest management. Problems with bark beetle are mentioned in media (TV, radio, press) very often, so people know about it.

The predominant majority of Sumava respondents and Nove Hrady Mts. respondents cumulatively stated that access to the disputed regions should not be made. In the case of regulated access of tourists to such natural areas, they would give preference to "access with a guide". A smaller section of the Nove Hrady Mts. respondents thought that access to the places with most endangered environment "should probably be allowed" or "should be allowed without restrictions". In the case of regulated access of tourists to such natural areas, they would give preference to "access with a guide". An interesting comparison is suggested by the survey in the Podyji NP, where $62.2 \%$ of the inhabitants would allow tourists into similar places [33] whereas, on the other hand, in Krkonose NP it was $55.9 \%$ against [44]. IUCN mentions tourism as one of the largest threats to protected areas and locals in Sumava and in the Nove Hrady Mts. have the same opinion perhaps - they are against public access to the most endangered parts of the nature [45].

Majority of respondents in Sumava thought that the current state of nature conservation in Sumava is satisfactory or "rather strict". The remaining respondents either did not know or did not have an opinion.

The majority of Nove Hrady Mts. respondents thought that the current state of nature conservation in the Nove Hrady Mountains is satisfactory. In the Krkonose NP, conservation management was sufficient according to $34 \%$ of the local respondents, and strict or too strict according to $18.6 \%$ [44].

\subsection{Tourism}

The majority of Sumava respondents did not report any economic benefit from the tourist industry at the time of the survey. The vast majority of the Nove Hrady Mts. respondents did not report any economic benefit from the tourist industry at the time of the survey too. This factor makes it the best example of involvement of locals in tourism related activities, although some opportunities could be exploited more effectively.

The uneven distribution of revenues from the tourist industry is a common problem, and frequently the profit goes only to a few individuals or families [46,31]. On the other hand, profit levels are usually connected to conservation and environmental values and to the ability of local people to accept such values. In the Podyji NP in 2000 , only $11.6 \%$ of the local inhabitants indicated an economic benefit [33]. A very different situation was found in the Krkonose NP, where an economic benefit was declared by $65.9 \%$ of the local inhabitants [44]. The results from the Nove Hrady Mountains and Sumava can be indirectly compared to the results from the Prespes NP in Greece, where $49.5 \%$ of locals thought that the existence of the national park had no influence on their economic situation, $27 \%$ of the respondents thought that due to the existence of the NP their situation had worsened and $15.8 \%$ of respondents indicated that their economic situation had improved after the establishment of the NP [3]. The local inhabitants in the Swiss nature reserve BR Etlebuch viewed the existence of their BR as a driving force for the development of the economy and job market [4]. Locals in Sumava and in Nove Hrady Mts. should be more enterprising and try to carry business in tourist industry.

According to the majority of Sumava respondents the numbers of visitors in the region approximately around the time of the survey were increasing rapidly or moderately. Similar situation is in the Nove Hrady Mts. It could be chance for local people and for whole region. They could have economic benefit from tourism. The increasing number of visitors was similarly indicated by the majority of respondents (54.8\%) in the Podyji NP [33]. We also cannot neglect the influence on the real number of visitors coming to the area, of the increase in services and the development of resorts i.e. the exploration phase in terms of the destination life cycle. An increased frequency of encounters with other visitors spoils the experience. The main principle of leisure activity in the countryside is the feeling of privacy, which is disturbed by the presence of other visitors [47]. The social tolerability of leisure activities in a certain area is characterrized by a subjective feeling of "overcrowding" the area with visitors. It is necessary to develop the areas sustainable with an emphasis on mitigating of negative effects.

The majority of Sumava and Nove Hrady Mts. respondents do not mind the intensity of tourism on the tourist routes. The intensity of tourism near the respondents' residence was perceived in a similar way: respondents did not find it disturbing. Results from the Podyji NP also show that people mostly (77.8\%) do not find tourism disturbing [33], neither did the inhabitants of the Krkonose NP, where $84.7 \%$ were not disturbed by tourists on tourist routes. Majority of respondents $(86 \%)$ were not disturbed by tourists near their homes in Krkonose [44]. It is necessary to note that overcrowding of the area by tourists can, for the local inhabitants, lead to the feeling of being "foreigners in their own land", which can subsequently cause enmity towards the visitors. For 
comparison, similar surveys in Finland show that only $11.8 \%$ of inhabitants living near protected areas have a negative attitude towards tourism [29]. No significant negative attitude towards tourist traffic in Sumava or in the Nove Hrady Mts. was found. But locals in the Sumava NP felt disturbed a bit more. It is logically, because in Sumava there is much bigger visit rate than in Nove Hrady Mts.

A different point of view on the interaction between the visitors and the local inhabitants is revealed by a more economically focused question dealing with the projection of the presence of the visitors' group onto the level of prices and the cost of living of the local inhabitants' group (among other things the prices in shops, prices of services, etc.). According to Sumava and Nove Hrady Mts. respondents the presence of tourists more likely or definitely raises their cost of living in comparison to other regions. In other national parks the majority of the locals also thought that the presence of tourists increased the cost of living in the area. In the Podyji NP it was 59.1\% [33] and in the Krkonose NP, the NP most affected by the tourism and leisure industry, it was $94.1 \%$ [44].

But it is real fact, that prices in shops in tourist areas are higher than prices in other regions of the Czech Republic. It is caused by high demand and low competition.

\section{Conclusions}

The outputs from the work should contribute to the collection of the national monitoring of reflections, opinions and attitudes which has been carried out in the environmental areas, namely in the national parks and in the biosphere reserves, from the mid-nineties to the present day. The second aim of the survey was to map the current situation in the selected Czech border regions from the point of view of the socio-demographic data of a sample of local inhabitants of the Nove Hrady Mts. and the Sumava NP, their authentic reflection of natural and environmental conditions, as well as the assessment of the existing conservation management. The next targets of our study were the attitudes of this important group towards the tourist industry in their area: towards its economic and environmental consequences. The following findings have been selected as being the most important:

Very similar or identical reflections were found in the assessment of personal profit from the tourist industry in the region and in the demographic characteristics of the respondents: sex, age structure, education.

A significant difference in opinions and attitudes between Sumava and the Nove Hrady Mts. inhabitants was seen in their opinions on the state of the environment in recent years (since approximately the year 2000), aware- ness of a specific environmental problem in the area, their attitude to public access to the most endangered natural areas of the Sumava and the Nove Hrady Mountains (both respondent groups would prefer access with a professional guide), and their opinions on the current level of conservation management. Additional differences were in the perception of the numbers of visitors, the psychological tolerability of the area-the intensity of tourism along the tourist routes and near the respondents' homes (neither group of respondents found it disturbing), and in the influence of tourism on the cost of living.

Nove Hrady Mts. area is milder probably because of the fact that the Sumava NP is much larger, is visited by many more tourists as well and it is better known to the general public. It is clear that the mind of local inhabitants in the traditional tourist destination Sumava is different from the mind of local inhabitants in the new discovered tourist destination - the Nove Hrady Mts. These results could start new discussion about establishment of the Protected Landscape Area in the Nove Hrady Mts.

The whole range of problems which we encounter in conservation management is simply caused by a lack of connection between the deciding authority and the needs of the local community. There is, however, a different point of view: one of the basic problems of the protected areas is the fact that during the process of their establishment, the needs and the opinions of the local communities are usually not taken into consideration. The residents then often feel it to be unjust that someone who does not live in their region has established a protected area and in this way can ban or limit the activities which have been normal amongst the local population for generations, without asking them. The main result should be an improvement in the standard of living of local inhabitants and their pride in living in a protected territory. It is a generally accepted fact that the public needs to be informed, educated and encouraged to participate in the management and development of their area.

\section{REFERENCES}

[1] A. D. Williams and G. Shaw (Eds.), "Tourism, Leisure, nature Protection and Agritourism: Principles, Partnership and Practice," European Power Electronics and Drives, University of Exeter, Exeter, 1996, p. 188.

[2] C. C. Konijnendijk, "A Decade of Urban Forestry in Europe," Forest Policy and Economics, Vol. 5, No. 2, 2003, pp. 173-186. doi:10.1016/S1389-9341(03)00023-6

[3] D. Trakolis, “Local People's Perceptions of Planning and Management Issues in Prespes Lakes National Park, Greece," Journal of Environmental Management, Vol. 61, No. 3, 2001, pp. 227-241. doi:10.1006/jema.2000.0410

[4] A. Wallner, N. Bauer and M. Hunziker, "Perceptions and 
Evaluations of Biosphere Reserves by Local Residents in Switzerland and Ukraine," Landscape and Urban Planning, Vol. 83, No. 2-3, 2007, pp. 104-114.

doi:10.1016/j.landurbplan.2007.03.006

[5] E. T. Byrd, H. E. Bosley and M. G. Dronberger, "Comparisons of Stakeholder Perceptions of Tourism Impacts in Rural Eastern North Carolina," Tourism Management, Vol. 30, No. 5, 2009, pp. 693-703.

doi:10.1016/j.tourman.2008.10.021

[6] J. Beltran (Ed.), "Indigenous and Traditional People and Protected Areas: Principles, Guidelines and Case Studies," The World Conversation Union, Gland, Switzerland and Cambridge, UK and WWF International, Gland, Switzerland, 2000, p. 133.

[7] B. B. Faust and R. C. Smardom, "Introduction and Overview: Environmental Knowledge, Rights and Ethics: Co-managing with Communities," Environmental Science \& Policy, Vol. 4, No. 4-5, 2001, pp. 147-151. doi:10.1016/S1462-9011(01)00025-9

[8] A. N. Songorwa, "Community-Based Wildlife Management (CWM) in Tanzania: Are the Communities Interested?," World Development, Vol. 27, No. 12, 1999, pp. 2061-2079. doi:10.1016/S0305-750X(99)00103-5

[9] A. Gbadegesin and O. Ayileka, "Avoiding the Mistakes of the Past: Towards a Community Oriented Management Strategy for the Proposed National Park in Abuja-Nigeria," Land Use Policy, Vol. 17, No. 2, 2000, pp. 89-100. doi:10.1016/S0264-8377(00)00005-3

[10] M. Hockings, S. Stolton and N. Dudley, "Evaluating Effectiveness: A Framework for Assessing the Management of Protected Areas," The World Conversation Union, Gland, Switzerland and Cambridge, UK, 2000, p. 121.

[11] Y. Lü, L. Chen, B. Fu and S. Liu, "A Framework for Evaluating the Effectiveness of Protected areas: The Case of Wolong Biosphere Reserve," Landscape and Urban Planning, Vol. 63, No. 4, 2003, pp. 213-223. doi:10.1016/S0169-2046(02)00193-7

[12] D. Kusova, M. Bartos and J. Tesitel, "Potential Development of the Right Shore of Lipno Lake Area: Comparision of Landscape and Urban Planning Documentation with ideas of Local Inhabitants," Silva Gabreta, Vol. 3, No. 3, 1999, pp. 217-228.

[13] E. H. Zube and M. L. Busch, "Park-People Relationships: An International Review," Landscape and Urban Planning, Vol. 19, No. 2, 1990, pp. 117-131. doi:10.1016/0169-2046(90)90030-6

[14] G. E. Pavlikakis and V. A. Tsihrintzis, "A Quantitative Method for Accounting Human Opinion, Preferences and Perceptions an Ecosystem Management," Journal of Environmental Management, Vol. 68, No. 2, 2003, pp. 193-205. doi:10.1016/S0301-4797(03)00067-7

[15] F. Bowcutt, "Ecological Restoration and Local Communities: A Case Study from Sinkyone Wilderness State Park, Mendocino Country, California," Human Ecology, Vol. 27, No. 2, 1999, pp. 359-368. doi:10.1023/A:1018733529690
[16] A. P. Castro and E. Nielsen, "Indigenous People and Co-management: Implications for Conflict Management," Environmental Science \& Policy, Vol. 4, No. 4-5, 2001, pp. 229-239. doi:10.1016/S1462-9011(01)00022-3

[17] G. E. Pavlikakis and V. A. Tsihrintzis, "Perceptions and Preference of the Local Population in Eastern Macedonia and Thrace National Park in Greece," Landscape and Urban Planning, Vol. 77, No. 1-2, 2006, pp. 1-16. doi:10.1016/j.landurbplan.2004.12.008

[18] A. Pizam, "Tourism Impacts: The social Costs to the Destination Community as Perceived by Its Residents," Journal of Travel Research, Vol. 16, No. 4, 1978, pp. 8-12. doi:10.1177/004728757801600402

[19] R. Varley, "Tourism in Fiji: Some Economic and Social Problems," University of Wales Press, Cardiff, 1978.

[20] F. J. Belisle and D. R. Hoy, "The Perceived Impact of Tourism by Residents: A Case Study in Santa Maria, Columbia," Annals of Tourism Research, Vol. 7, No. 1, 1980, pp. 83-101. doi:10.1016/S0160-7383(80)80008-9

[21] L. Vusoniwailala, "Tourism and Fijian Hospitality: In Pacific Tourism as Islanders See It," R. Crocombe and F. Rajotte Eds., Institute of Pacific Studies, University of South Pacific, Suva, 1980.

[22] B. Andressen and P. E. Murphy, "Tourism Development in Canadian Travel Corridors: Two Surveys of Resident Attitudes," World Leisure and Recreation, Vol. 28, No. 5, 1986, pp. 17-22.

[23] A. Milman and A. Pizam, "Social Impacts of Tourism on Central Florida," Annals of Tourism Research, Vol. 15, No. 2, 1988, pp. 191-204. doi:10.1016/0160-7383(88)90082-5

[24] E. A. Fiallo and S. K. Jacobson, "Local Communities and Protected Areas: Attitudes of Rural Residents towards Conservation in Machalilla National Park, Equador," Environmental Conservation, Vol. 22, No. 3, 1995, pp 241-249. doi:10.1017/S037689290001064X

[25] B. P. Kaltenborn, H. Riese and M. Hundeide, "National Park Planning and Local Participation: Some Reflections from a Mountain Region in Southern Norway," Mountain Research and Development, Vol. 19, No. 1, 1999, pp. 51-61. doi:10.2307/3674113

[26] F. Yuksel, B. Bramwell and A. Yuksel, "Stakeholder Interviews and Tourism Planning at Pamukkale, Turkey," Tourism Management, Vol. 20, No. 3, 1999, pp. 351-360. doi:10.1016/S0261-5177(98)00117-4

[27] M. Bonaiuto, G. Carrus, H. Martorella and M. Bonnes, "Local Identity Process and Environmental Attitudes in Land Use Changes: The Case of Natural Protected Areas," Journal of Economic Psychology, Vol. 23, No. 5, 2002, pp. 631-653. doi:10.1016/S0167-4870(02)00121-6

[28] K. S. Rao, S. Nautiyal, R. K. Maikhuri and K. G. Saxena, 'Local Peoples' Knowledge, Aptitude and Perceptions of Planning and Management Issues in Nanda Devi Biosphere Reserve, India," Environmental Management, Vol. 31 , No. 2, 2003, pp. 168-181. doi:10.1007/s00267-002-2830-4 
[29] A. Törn, P. Siikamaki, A. Tolvanen, P. Kauppila and J. Ramet, "Local People, Nature Conservation, and Tourism in Northeastern Finland," Ecology and Society, Vol. 13, No. 1, 2008, p. 18.

[30] A. Diedrich and E. García-Buades, "Local Perceptions of Tourism as Indicators of Destination Decline," Tourism Management, Vol. 30, No. 4, 2009, pp. 512-521. doi:10.1016/j.tourman.2008.10.009

[31] S. Richardson, "Undergraduates' Perceptions of Tourism and Hospitality as a Career Choice," International Journal of Hospitality Management, Vol. 28, No. 3, 2009, pp. 382-388. doi:10.1016/j.ijhm.2008.10.006

[32] M. Cihar, Z. Tancosova and V. Trebicky, "Narodni Park Sumava a Vybrane Aspekty Jeho Udrzitelneho Rozvoje-Hodnoceni Mistnimi Obyvateli/obce Borova Lada, Horska Kvilda, Kvilda, Modrava, Filipova Hut, Srni a Prasily. (The Sumava National Park and Selected Aspects of Its Sustainable Development-Evaluation by the Local People/Communities of Borova Lada, Horska Kvilda, Kvilda, Modrava, Filipova Hut, Srni a Prasily)," Silva Gabreta, No. 5, 2000, pp. 195-216.

[33] M. Cihar and J. Stankova, "Attitudes of Stakeholders towards the Podyji/Thaya River Basin National Park in the Czech Republic," Journal of Environmental Management, Vol. 81, No. 3, 2006, pp. 273-285. doi:10.1016/j.jenvman.2005.11.002

[34] CZSO (The Czech Statistical Office), "Population, Housing and Household Data-Czech Republic," Prague, Czech Republic, 2008.

[35] P. Gavora, "Introduction to Educational Research," Brno, Paido, Edition of Pedagogical Literature, Czech Republic, 2000.

[36] N. K. Denzin and Y. S. Lincoln, "Handbook of Qualitative Research," 2nd Edition, Sage Publications, Thousand Oaks, 2000.

[37] M. Q. Patton, "Qualitative Research \& Evaluation Methods," 3rd Edition, Sage Publications, Thousand Oaks, 2002.
[38] M. B. Miles and A. M. Huberman, "Qualitative Data Analysis," Sage Publications, Thousand Oaks, 1994.

[39] M. Disman, "How We Produce Sociological Knowledge," Prague, Czech Republic, 1993.

[40] M. Cihar, V. Trebicky and J. Novak, "Selected Indicators of Sustainable Tourism in the Central Part of the Sumava National Park and Biosphere Reserve," Silva Gabreta, No. 6, 2001, pp. 295-304.

[41] S. Stoll-Kleemann, "Barriers to Nature Conservation in Germany: A Model Explaning Opposition to Protected Areas," Journal of Environmental Psychology, Vol. 21, No. 4, 2001, pp. 369-385. doi:10.1006/jevp.2001.0228

[42] I. Pecakova, I. Novak and J. Hermann, "Acquisition and Data Evaluation in Public Opinion Polls," Prague, Faculty of Informatics and Statistics, Prague, University of Economics, Czech Republic, 2000.

[43] J. Hendl, "Prehled Statistickych Metod Zpracovani Dat: Analyza a Metaanalyza Dat," Praha, Portal, Czech Republic, 2006.

[44] M. Cihar et al., "Vybrane Ukazatele Udrzitelneho Turismu v Centralni Casti KRNAP a Jejich Monitoring (Selected indicators of sustainable tourism in the central part of the Krkonose National Park and Biosphere Reserve)," Faculty of Science, Charles University, Prague, unpublished report, 2004.

[45] IUCN (International Union for the Conservation of Nature), "World Heritage Twenty Years Later," Compiled by J. Thorsell, IUCN, Gland, Switzerland, 1992.

[46] S. Gössling, "Ecotourism: A Means of Safeguard Biodiversity and Ecosystem Functions?," Ecological Economics, Vol. 29, No. 2, 1999, pp. 303-320. doi:10.1016/S0921-8009(99)00012-9

[47] P. Deadman and R. H. Gimblett, "A Role for Goal-Oriented Autonomous Agents in Modeling People-Environment Interactions in Forest Recreation," Mathematical and Computer Modelling, Vol. 20, No. 8, 1994, pp. 121-133. doi:10.1016/0895-7177(94)90236-4 